\title{
Du traitement étiologique des AOS
}

\section{Etiological treatment of OSA}

\author{
Jacques TALMANT, Jean-Claude TALMANT, \\ Joël DENIAUD, Philippe AMAT
}

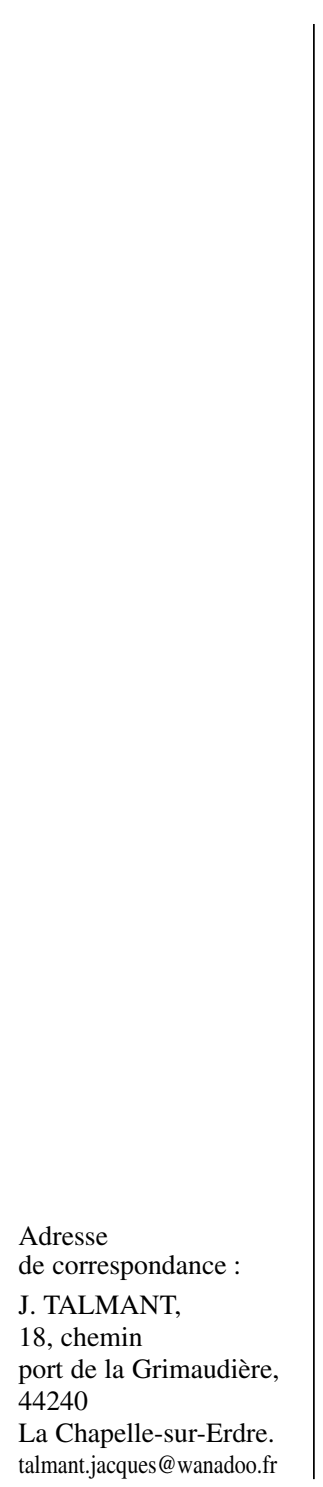

La fin du siècle précédent aura fait découvrir les «Apnées Obstructives du Sommeil (AOS)» aux praticiens de l'ODF. En trente ans, la recherche dans ce domaine s'est organisée, transformant profondément la qualité de vie des apnéiques, conviant même les orthopédistes dento-faciaux à contribuer à leur traitement symptomatique. Mais, parmi les points restés dans l'ombre, la cause même des ronflements qui déstabilisent le pharynx occupe encore une place à part.

Dans un exposé traitant de «Ventilation et mécanique de l'oropharynx», publié dans cette Revue il y a plus de dix ans ${ }^{16}$, nous avions proposé un mécanisme pouvant expliquer la survenue des AOS. Et nous recommandions une thérapeutique (que nous avions déjà testée chez l'enfant et l'adolescent) destinée à traiter la déstabilisation pharyngée au cours du sommeil. L'ensemble reposait sur :

- le développement anatomique postnatal spécifiquement humain de l'oropharynx (les autres primates ne font pas d'AOS) ;

- les changements physiologiques qui accompagnent ce développement (l'absence néonatale d'oropharynx est un atout morphologique quand le fluide ventilatoire devient brutalement aérien, alors que la coordination fonctionnelle du pharynx est encore marquée par la vie en milieu amniotique) ;

- les caractéristiques de la régulation homéostatique de sa lumière ;
At the end of the last century orthodontists began to become aware of "Obstructive Sleep Apnea (OSA)". And, over the past thirty years, research in this area has flourished, profoundly transforming the quality of life for patients who suffer from this syndrome, with dentofacial orthopedists actively participating in its symptomatic treatment. But, among the issues that remain incompletely elucidated, the actual cause of the snoring episodes that destabilize the pharynx still occupies an important position.

In an article dealing with "Ventilation and mechanics of the oro-pharynx" published in this journal ten years ago ${ }^{16}$, we proposed a mechanism that could account for the unanticipated arrival of OAS. And we suggested a therapeutic approach, that we had already tested on children and adolescent, that was designed to treat pharyngeal destabilization during sleep. In its ensemble, it is based on:

- the specifically human post-natal anatomic development of the oropharynx (other primates do not suffer from OAS);

- the physiological changes that accompany this development (the absence of an oropharynx in neonates is a morphological blessing that protects the newborn when its ventilatory fluid abruptly becomes aerated at a time when the functional coordination of the pharynx is still adapted to life in the amniotic milieu);

- the characteristics of the homeostatic regulation of its lumen; 
- le mécanisme de sa défaillance en cas d'AOS ;

- la possibilité d'y remédier à l'aide d'une expansion maxillaire «adaptée», permettant au patient de récupérer le contrôle physiologique de son pharynx, y compris la nuit pendant son sommeil.

La conclusion appelait donc les orthopédistes dento-faciaux à intervenir dans le traitement étiologique des AOS. Utilisée en temps opportuns, l'expansion maxillaire «adaptée» est en effet un acte à l'efficacité clinique éprouvée, capable de corriger le déficit transversal des fosses nasales et celui, plus important encore, des valves narinaires. Complétée chaque fois que nécessaire par le traitement immuno-allergologique de la muqueuse nasale, voire le traitement chirurgical des anomalies septales et/ou turbinales, elle contribue à la disparition de la cause des ronflements en optimisant la ventilation nasale et, partant, le fonctionnement du voile et du pharynx. Elle rend ainsi au patient son autonomie ventilatoire nocturne. Où en sommes-nous aujourd'hui ?
- the mechanism of OSA breakdown;

- the possibility of helping current or potential OSA patients with "adaptive" maxillary expansion that can assist patients in recovering physiological control of their pharynxes during nighttime sleeping as well as during the day.

The message of our essay was that dentofacial orthopedists should contribute to the etiological treatment of OSA. Utilized at the proper time, "adaptive" maxillary expansion is an effective, tested clinical procedure capable of correcting the transverse deficit of the nasal fossa and the nasal valves still narrower. Supplemented whenever indicated with immunoallergical treatments of the nasal mucosa, and, in certain cases, surgical intervention to correct septal and/or turbinal anomalies, palatal expansion helps to eliminate the causes of snoring and optimizes the framework for nasal breathing as it restores proper function of the soft palate and of the pharynx. In this way patients benefit from a restoration of correct nocturnal breathing. Where do we stand today in dealing with OSA?
Depuis 1993, le National Center on Sleep Disorders Research, au sein du National Heart Lung and Blood Institute, a été mandaté par les National Institutes of Health pour conduire et soutenir la recherche sur le sommeil et ses troubles. Selon cet organisme, les Troubles Ventilatoires du Sommeil (TVS) (Sleep-Disordered Breathing ou SDB en anglais) regroupent des affections caractérisées par des anomalies qualitatives (pauses) ou quantitatives de la ventilation au cours du sommeil. L'AOS, le plus commun d'entre eux, est caractérisée par le collapsus répété, complet ou partiel, du pharynx au cours du sommeil, et par la nécessité d'un réveil pour que reprenne la ventilation. Ces interruptions répétées du sommeil préludent à la somnolence diurne et à la diminution des performances cognitives. Associée à
Since 1993, the American National Center on Sleep Disorders Research, a division of the National Heart Lung and Blood Institute, has been mandated by the National Institutes of Health to conduct and support research on sleep and sleep disorders. According to this organization, Sleep-Disordered Breathing (SDB) is a category that encompasses all qualitative (pauses) or quantitative anomalies of night time breathing. OSA, the most common of these problems, is characterized by repeated complete or partial collapse of the pharynx during sleep, which forces the patient to awaken in order to resume respiration. These frequent interruptions of nightly sleep provoke periods of daytime somnolence and a decrease in the quality of cognitive performance. Associated as they are 
l'hypoxie et à l'hypercapnie intermittentes, la récurrence de ces réactions d'éveil semble impliquée dans la survenue de complications cardiovasculaires. Enfin ces troubles contribueraient à l'insulinorésistance et à d'autres composantes du syndrome métabolique qui les accompagne.

Malgré les progrès techniques considérables dont a bénéficié la polysomnographie, essentielle au dépistage des TVS, nombre des victimes de cette pathologie ne sont pas diagnostiquées ; et la ventilation en pression positive continue, approche thérapeutique symptomatique efficace mais inconfortable, n'entraîne pas une adhésion optimale des patients, d'autant qu'elle doit être poursuivie toute la vie. Globalement, la compréhension des mécanismes neurobiologiques qui altèrent le contrôle moteur des voies aérifères supérieures (VAS) au cours du sommeil et conduisent au collapsus du pharynx, reste très incomplète. Et l'on ne sait toujours pas jusqu'à quel point les TVS observés chez les patients plus âgés représentent les mêmes troubles que ceux qu'on rencontre dans les populations plus jeunes, ni s'ils demandent le même traitement.

Chez l'enfant, le ronflement, symptôme de la résistance accrue des VAS au cours du sommeil, est très fréquent, touchant aussi bien le nourrisson que l'enfant plus âgé. Mais, comme chez l'adulte, la physiopathologie des TVS reste mal comprise. L'hypertrophie adénoamygdalienne contribue certainement à ces TVS, mais d'autres facteurs tels l'obésité, la génétique crânio-faciale et les mécanismes du contrôle neurologique de la perméabilité des VAS paraissent aussi importants 6,12 . De plus, l'étendue des troubles associés aux TVS de l'enfant s'est elle aussi progressivement élargie, affectant principalement les systèmes cardiovasculaires et neuropsychologiques. Ils prennent la forme d'une hypertension pulmonaire, d'une hypertension artérielle, d'une énurésie nocturne, d'un retentissement sur la croissance somatique, de déficits d'apprentissage et cognitifs, et de problèmes comportementaux du type trouble déficitaire de l'attention associé à l'hyperactivité. Certaines de ces associations pathologiques avaient déjà été identifiées dans le rapport présenté devant la SFODF en $1982^{15}$. with intermittent hypoxia and hypercapnia, repeated episodes of awakening are implicated in the development of cardiovascular complications. In addition, there is evolving evidence that SDB may contribute to insulin resistance and other components of the metabolic syndrome.

Despite considerable progress in polysomnography, an essential tool for detection of SDB, most patients remain undiagnosed; and the efficient symptomatic therapeutic approach, continuous positive airway pressure, remains somewhat cumbersome, worse still must be repeated every night for life and hence is not associated with optimal compliance rates. We continue to have a very incomplete understanding of the neurobiological mechanisms responsible for the sleepinduced changes in upper airway motor control that lead to pharyngeal collapse. And we still do not know to what extent SDB in the elderly represents the same disorder as is encountered in younger populations and thus deserves similar therapy.

Snoring, a symptom of increased upper airway resistance during sleep, is extremely frequent in childhood, and affects infants as well as older children. The pathophysiology of SDB in children as in adults is still poorly understood. While adenotonsillar hypertrophy is certainly a major contributor to SDB, others factors such as obesity, craniofacial genetics, and neural control mechanisms of upper airway patency also appear to be important ${ }^{6}$, 12. In addition, the extend of problems endured by children with SDB enlarges progressively, having now recognized cardiovascular and neurobehavioral consequences. These morbidities include pulmonary hypertension, arterial hypertension, nocturnal enuresis, reduced somatic growth, learning and cognitive deficits, and behavioral problems that resemble attention deficit-hyperactivity disorder. A report presented to the Société Française d'Orthopédie Dento-Faciale in $1982^{15}$ identified some of these associations. 
Pour de nombreux cliniciens, le ronflement et les TVS ne sont pas aussi bénins qu'on a pu le croire, sachant surtout que les patients apnéiques sont des ronfleurs longtemps avant que ne se manifeste leur symptomatologie obstructive. Or l'intensité sonore des ronflements attire l'attention sur la nocivité des contraintes que l'énergie mécanique de ces vibrations déploie au sein des tissus mous du pharynx ${ }^{1,4,16}$. Animées chaque nuitée par les turbulences naso-pharyngées du courant inspiratoire et transmises par les vibrations du voile et de ses piliers aux parois latérales du pharynx et à la base linguale, ces vibrations engendrent au sein des parois pharyngées des lésions traumatiques reconnues comme telles dans nombre de travaux anatomopathologiques, les caractéristiques des ronfleurs sévères ne différant pas qualitativement de celles des apnéiques 3,17 . Les travaux plus récents confirment que la déstabilisation du pharynx peut résulter de la détérioration muqueuse ${ }^{11}$, musculaire ${ }^{14}$, et/ou nerveuse $2,13,14$ de l'un et/ou l'autre des deux versants, sensitif et moteur, du mécanisme qui contrôle les effets géométriques du gradient inspiratoire sur la lumière pharyngée. Ainsi, la démonstration EMG est faite qu'une énervation chronique partielle peut atteindre le muscle palato-pharyngien dans les $\mathrm{AOS}^{5,14}$. Bref, des changements structuraux, secondaires aux traumatismes vibratoires engendrés par les ronflements, peuvent toucher chacune des composantes des structures pharyngées, et contribuer à la collapsibilité de ce segment des voies aérifères.

Ajoutons que l'imagerie cérébrale d'adultes manifestant des $\operatorname{AOS}^{8,10}$ a montré des changements morphologiques de la substance grise intéressant des régions comme le cervelet si important dans l'initiation de l'inspiration ${ }^{8}$. De même, une étude récente a montré des altérations métaboliques à hauteur de l'hippocampe et du cortex frontal chez des enfants présentant des AOS, en association avec des déficits neuropsychiques, témoignant d'une possible lésion nerveuse associée à l'AOS $^{5}$. Toutefois l'amélioration de la
Many clinicians have come to believe that SDB are not as innocuous as previously thought, especially in view of the observation that patients begin snoring long before they display indications of obstructive symptoms. In fact, the intensity of the snoring draws attention to the harmful effect of the stresses the mechanical energy of these vibrations apply on the pharyngeal soft tissues $1,4,16$. Driven every night by the turbulent flow of the nasopharyngeal inspiratory air and transmitted by the soft palate and its pillars on the lateral pharyngeal walls and the base of the tongue, these vibrations give rise to traumatic lesions on these soft tissues as has been shown in numerous pathologico-anatomic studies; the characteristics of profound snorers do not differ qualitatively from those of apnea patients 3,17 .

Recent studies confirm that destabilization of the pharynx can be a result of deterioration of its mucosall1, muscular ${ }^{14}$, and/or neural ${ }^{2}, 13,14$ components of either or both sides, sensory or motor, of the mechanism that controls the geometric effects of the inspiratory gradient on the pharyngeal lumen. Accordingly, electromyography analyses show that chronic partial enervation of the palatopharyngeal muscle can occur during episodes of $\mathrm{OSA}^{5,14}$. In short, structural changes, side effects of the vibration trauma related to snoring, can affect every component of the pharyngeal complex, and contribute to collapse of this segment of the airways.

It is interesting to note that cerebral imagery of adults afflicted with $\mathrm{OSA}^{8,10}$ has pictured morphological changes of the grey matter affecting regions like the cerebellum that are vitally important in the initiation of inspiration ${ }^{8}$. Similarly, a recent study has shown metabolic alterations at the level of the hippocampus and the frontal cortex in children suffering from OSA in association with neuropsychic deficits that suggest a possible neural lesion related to $\mathrm{OSA}^{5}$. 
réponse des VAS après traitement de l'AOS de l'enfant ${ }^{9}$ soutient indirectement le concept d'après lequel ces altérations nerveuses centrales sont la conséquence de l'AOS plutôt qu'elles n'en précèdent le développement. Si ces concepts sont validés, le diagnostic précoce et le traitement de l'AOS de l'enfant devraient protéger le fonctionnement neurologique.

En sorte que l'important reste le traitement étiologique de la cause des ronflements : la pathologie nasale et ses conséquences sur les caractéristiques de l'écoulement inspiratoire en amont du pharynx.
However, it is important to note that the improvement in upper airway answer that children display after OSA treatment ${ }^{9}$ gives indirect support to the concept asserting that central nervous system alterations are a result of, not a cause of OSA. If this view is correct, early diagnosis and treatment of OSA in children should protect their neurological functioning. The conclusion to be drawn from all these studies is the importance of etiological treatment of the cause of snoring: the breathing disorders of nasal airways and their consequences on the inspiratory airflow through the pharynx.

\section{CONCLUSION}

La conclusion devient simple, claire, éloquente, enthousiasmante même par l'opportunité pour les spécialistes de l'O.D.F. de s'engager dans le traitement étiologique des AOS. En usant des possibilités uniques qu'offrent leurs techniques d'optimiser des formes définitivement compromises s'ils n'interviennent pas. Autrement dit en œuvrant sur des formes qui, livrées à ellesmêmes, dégradent si profondément la qualité de vie de ces patients qu'elles les exposent à des complications mettant en jeu leur pronostic vital. L'expansion maxillaire «adaptée», capable de desserrer l'étreinte suffocante du pharynx née de l'étroitesse des valves narinaires et des fosses nasales, est un geste propre à apporter une correction à caractère étiologique. Lorsqu'on l'exécute suffisamment tôt au cours du développement du patient, les AOS ne représentent plus qu'un épisode dans la vie agitée d'un pharynx qui peut ne plus en porter la marque définitive.

Assurément, la connaissance des AOS conduit à réaliser toute l'étendue du complexe fonctionnel auquel la face est reliée. La «sourirologie» est devenue un néologisme bien désuet. La vision de l'orthodontiste selon laquelle le travail bien fait pourrait se limiter à la seule optimisation morphologique des arcades alvéolodentaires a vécu. Comme a vécu la conception de la chirurgie des fentes labio-narinaires et
Today we are justified in drawing the simple, clear, eloquent, even enthusiastic conclusion that orthodontic specialists occupy a privileged position for participating in the etiological treatment of OSA. By resorting to their unique technical capabilities of making shapes as functional as possible that would be definitively compromised if they did not take action. In others words, by reshaping facial structures that, untreated, would cause a profound deterioration of the quality of life of their patients and expose them to complications that could put at stake their prognosis for life. "Adaptive" palatal expansion, which is capable of freeing the pharynx from the suffocating constraints imposed by constricted nasal valves and nasal fossa, is truly an intervention that can deliver etiological correction. When this procedure is accomplished at a sufficiently early stage in patients' growth and development, OSA will prove to have been only a minor, if unpleasant, episode in the agitated functioning of a pharynx that may be able not to bear the permanent scare.

Assuredly, by gaining an understanding of OSA we are introduced to the full expanse of the functional complex with which the face is associated. "Smileology" has become a neologism thoroughly out of date. The vision of orthodontics stipulating that the treatment possibilities orthodontics can deliver would be limited to placing the teeth and 
palatines qui limitait ses objectifs à l'apparence superficielle des narines ou de la luette à la fin de l'intervention primaire. Dans tous ces contextes, l'expérience a montré, au-delà de toute restriction, qu'en élargissant l'objectif initial à l'optimisation fonctionnelle des structures ventilatoires de la face, les résultats orthopédiques comme chirurgicaux gagnaient indiscutablement en qualité. Désormais, l'objectif thérapeutique commun est formellement identifié : c'est à l'optimisation du développement de la face de leurs patients que contribuent 1'Orthopédie Dento-Faciale comme la chirurgie des fentes. C'est en optimisant directement le développement des capacités ventilatoires de leurs patients que ces traitements contribueront à optimiser indirectement leurs fonctionnements cardiovasculaires et neuropsychologiques. Cet objectif justifie pleinement l'investissement personnel de ces praticiens dans des formations longues et exigeantes. En atteignant cette cible, ils éprouveront la satisfaction partagée devant l'aboutissement de leur mission de santé publique ; et l'ODF parviendra ainsi à maturité, après avoir longtemps hésité à reconnaître sa véritable dimension.

Le conseil de René Dubos : «Penser globalement, agir localement» recelait décidément beaucoup de sagesse. their supporting dental arches in the best possible position has passed into oblivion. The same is true of the concept that surgical correction of cleft lips and palates has a simple objective of achieving a superficial improvement of the appearance of the nostrils and the uvula at the end of the first intervention. In all of these contexts, experience has shown that, over and above all restrictions, by enlarging the initial objective to optimizing the respiratory function of the face, the orthopedic as well as the surgical results achieve an indisputable gain in quality. We know that from now on the common therapeutic objective of the inter-disciplinary team of practitioners has been formally identified: it is to optimize the development of the faces of their patients with contributions that both dentofacial orthopedics and surgical correction of clefts can make. It is by acting directly to improve the breathing capacities of their patients that practitioners can contribute indirectly to ameliorating their cardiovascular and neuropsychological functioning. This objective fully justifies practitioners' personal investment in long and demanding educational programs. By reaching a new, more inclusive educational goal, they will derive the shared satisfaction of fulfilling their public health mission; and as doctors of dentofacial orthopedics they will thereby arrive at maturity after having for so many years hesitated to recognize the veritable dimensions of their calling.

René Dubos's advice "Think globally, act locally" certainly reflects the wisdom of a sage.

\section{BIBLIOGRAPHIE}

1. Bao G, Guilleminault C. Upper airway resistance syndrome: one decade later. Curr Opin Pulm Med 2004;10:461-7.

2. Boyd JH, Petrof BJ, Hamid Q, Fraser R \& Kimoff RJ. Upper airway muscle inflammation and denervation changes in obstructive sleep apnea. Am J Respir Crit Care Med 2004;170:541-6.

3. Edstrom L, Larsson H, Larsson L. Neurogenic effects on the palatopharyngeal muscle in patients with obstructive sleep apnoea: a muscle biopsy study. J Neurol Neurosurg Psychiatry 1992;55:916-20

4. Guilleminault C, Huang YS, Kirisoglu C, et al. Is obstructive sleep apnea syndrome a neurological disorder? A continuous positive airway pressure follow-up study. Ann Neurol 2005;58:880-7

5. Halbower AC, Degaonkar M, Barker PB, et al. Childhood obstructive sleep apnea associates with neuropsychological deficits and neuronal brain injury. PLoS Med 2006;3:e301

6. Halbower AC, Ishman SL, McGinley BM. Breathing Childhood Obstructive Sleep-Disordered. Chest 2007; 132:2030-41. 
7. Macey PM, Henderson LA, Macey KE, et al. Brain morphology associated with obstructive sleep apnea. Am J Respir Crit Care Med 2002;166:1382-7.

8. Macey PM, Woo MA, Macey KE, et al. Hypoxia reveals posterior thalamic, cerebellar, midbrain and limbic deficits in congenital central hypoventilation syndrome. J Appl Physiol 2004;98:958-69.

9. Marcus CL, Katz ES, Lutz J, et al. Upper airway dynamic responses in children with the obstructive sleep apnea syndrome. Pediatr Res 2005;57:99-107.

10. Morrell MJ, McRobbie DW, Quest RA, et al. Changes in brain morphology associated with obstructive sleep apnea. Sleep Med 2003;4:451-4.

11. Paulsen FP, Steven P, Tsokos M, Jungmann K, Müller A, Verse T, Pirsig W. Upper airway epithelial structural changes in obstructive sleep-disordered breathing. Am J Respir Crit Care Med 2002;166:501-9.

12. Praud JP, Dorion D. Obstructive sleep disordered breathing in children : beyond adenotonsillectomy. Pediatr Pulmonol 2008;43:837-43.

13. Saboisky JP, Butler JE, McKenzie DK, Gorman RB, Trinder JA, White DP, Gandevia SC. Neural drive to human genioglossus in obstructive sleep apnoea. J Physiol 2007;585.1:135-46.

14. Svanborg E. Impact of obstructive apnea syndrome on upper airway respiratory muscles. Respir Physiol Neurobiol 2005;147:263-72.

15. Talmant J, Rouvre M, Thibult JL et al. Contribution à l'étude des rapports de la ventilation avec la morphogenèse craniofaciale. Déductions thérapeutiques concernant l'ODF. Orthod Fr 1982;53:7-181.

16. Talmant J, Renaudin S, Renaud P. Ventilation et mécanique de l'oro-pharynx. Rev Orthop Dento-faciale 1998;32:105-66.

17. Woodson BT, Garancis JC, Toohill RJ. Histopathologic changes in snoring and obstructive sleep apnea syndrome. Laryngoscope 1991;101:1318-22.

\section{Revue d'Orthopédie Dento
Faciale}

Volume $42 / 2008$

Mewe trimesiniens:

hemen 1

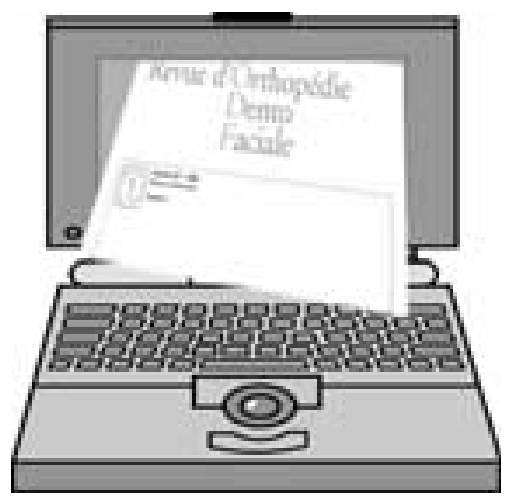

La Revue d'O.D.F.

à votre service

sur Internet

www.revue-odf.org 